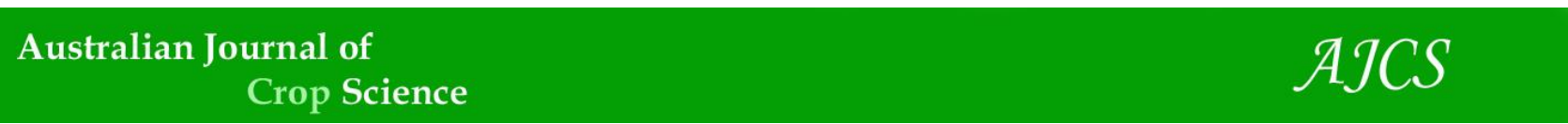

AJCS 15(06):899-908 (2021)

ISSN:1835-2707

doi: 10.21475/ajcs.21.15.06.p3135

\title{
Nutritional and biomass aspects of Helianthus annuus according to boron application in the soil
}

\author{
Aline Franciel de Andrade ${ }^{1}$, Karen Andreon Viçosi ${ }^{2}$, Amanda Magalhães Bueno ${ }^{1}$, Rilner Alves Flores ${ }^{1 *}$, \\ Carlos Leandro Rodrigues dos Santos ${ }^{3}$, Glenio Guimarães Santos ${ }^{1}$, Marcio Mesquita ${ }^{1}$
}

${ }^{1}$ Federal University of Goiás (UFG), College of Agronomy, Avenida Esperança, Campus Samambaia, 74690900, Goiânia, GO, Brazil

${ }^{2}$ Federal University of Espírito Santo (UFES), Center for Agricultural Sciences and Engineering, Alto Universitário, Guararema, 29500-000, Alegre, ES, Brazil

${ }^{3}$ Federal University of Mato Grosso (UFMT), Exact Sciences and the Earth Institute (ICET), Valdon Varjão avenue, Campus Araguaia, 78607-059, Barra de Garças, MT, Brazil

\section{*Corresponding author: rilner@ufg.br}

\begin{abstract}
Sunflower is considered highly demanding in boron (B); however, it has low efficiency in using this micronutrient. An experiment under protected cultivation was carried out to evaluate the effects of boron fertilization on nutrition and sunflower biomass production (Helianthus annuus). A completely randomized design with four replications was used. Five boron doses: 0 (Control), 1, 2,3 , and $4 \mathrm{~kg} \mathrm{ha}^{-1}$, were applied to the soil using boric acid as the source. Biometric assessments, measurements of the relative chlorophyll index $(\mathrm{RCl})$, production of dry biomass and the boron use efficiency by plants were carried out. The data were subjected to analysis of variance and $\mathrm{F}$ test $(\mathrm{p}<0.05)$, with polynomial regression analysis when significant. Leaf area, $\mathrm{RCl}$ evaluated at 15 and 60 days, and biomass increase linearly according to the boron application up to the dose of $4 \mathrm{~kg} \mathrm{ha}^{-1}$, which corresponds to an increase of $31,12,14$, and $61 \%$, respectively, compared to control treatment. However, for plant height and nutritional efficiency, the best results were obtained with the dose of $2.64 \mathrm{~kg} \mathrm{ha}^{-1}$ of $\mathrm{B}$, with a decrease in higher doses. Boron fertilization in sunflower crop positively influences the nutritional and growth aspects of plants. In general, the application of up to $3 \mathrm{~kg} \mathrm{ha}^{-1}$ of B in soils with low natural content increases the crop yield, without phytotoxicity aspects caused by the nutrient.
\end{abstract}

Keywords: Micronutrients; Nutritional efficiency; Plant nutrition; Soil fertility; Sunflower.

Abbreviation ABef_absorption efficiency; B_Boron; BAS_Boron accumulation in the shoot; BAP_Boron accumulation in the whole plant; CEC_Cation exchange capacity; DAE_Days after emergence; IAA_Indole acetic acid; KCl_Potassium chloride; PN_Neutralizing power; PRNT_Total neutralizing relative power; RCI_Relative chlorophyll index; RNA_Ribose nucleic acid; TRef_Transport efficiency; UTef_Use efficiency for conversion to dry matter.

Introduction

Sunflower (Helianthus annuus L.) is an annual crop, originally from North America, being one of the four most important oilseeds in the world. Despite being native to a temperate climate region, due to its high drought tolerance and adaptation to a wide variety of soils, latitude, longitude, and photoperiod, it has been cultivated in several regions of the world (Vilvert et al., 2018). The sunflower crop occupies around 26 million hectares worldwide, with approximately 47 million tons (Khalid et al., 2020). In Brazil, the production estimate for the $2019 / 20$ crop is 98.1 thousand tons, with an average yield of $1,581 \mathrm{~kg} \mathrm{ha}^{-1}$ (Conab, 2019), higher than the world average yield $\left(1,300 \mathrm{~kg} \mathrm{ha}^{-1}\right)$. Nevertheless, according to Gomes et al. (2012), Brazilian sunflower production is still below its potential with nutritional management (Kaleri et al., 2019) associated with supplementary irrigation, the main factors involved that can increase the productive capacity of the crop.
The sunflower is considered a highly demanding plant in nutrients, among them boron (B). However, it has low efficiency regarding its use, and it is common to observe symptoms of nutritional disorders due to deficiency in the main grain-producing regions of Brazil (Souza et al., 2004; Euba Neto et al., 2014). In the Brazilian Cerrado region, where the largest sunflower planted area is concentrated, B deficiency in the soil occurs more frequently (Capone et al., 2016). This region is characterized by highly weathered soils (Landi et al., 2019), with a low natural content of exchangeable bases, high acidity, concentrated rainy season, followed by the dry season, both with high temperatures and an average rainfall of $1,486 \mathrm{~mm}( \pm 146.8$ $\mathrm{mm}$ ) (Campos and Chaves, 2020; Penereiro et al., 2020). All these factors are detrimental to the maintenance of organic matter contents in the soil, the main source of boron availability for plants (Das et al., 2019). 
The low organic matter content in the soil usually favors a lower $\mathrm{B}$ concentration at levels below those considered adequate $\left(<0.20 \mathrm{mg} \mathrm{dm}^{-3}\right)$ for crop nutrition. According to Prado (2008), whenever the B concentration in the soil is lower than adequate, there is potential for the plants to respond to its supply. Alkaline soils, with a sandy texture and low organic matter content $(<1.5 \%)$, negatively affect crop yield (Sobral et al., 2015; Jegadeeswari and Muthumanickam, 2017). On the other hand, in clayey soils (>35\% clay), applications must be judicious, as high concentrations of B cause toxic effects on plants, affecting crop production (Camacho-Cristóbal et al., 2008). However, there is no consensus in the recent literature on which dose of boron is considered toxic for sunflower production, which varies between 1.0 and $3.0 \mathrm{~kg} \mathrm{ha}^{-1}$, with reduced development and grain yield at higher doses (Bhattacharyya et al., 2015; Capone et al., 2016; Dhassi et al., 2019; Khalid et al., 2020).

In the literature, it is observed that $B$ is essential for sunflower growth, which affects the dry biomass and grain yield (Souza et al., 2004; Öztürk et al., 2010; Euba Neto et al., 2014; Tahir et al., 2014; Silva et al., 2016; Alves et al., 2017). This behavior of plants is directly related to the functions that B plays in the metabolism and integrity of the cell wall, besides affecting cell division, development of fruits and seeds, transport of sugars, development of hormones, and metabolism of $\mathrm{N}, \mathrm{Ca}, \mathrm{P}$, and $\mathrm{K}$ in plants (Mehmood et al., 2018). Also, the formation of leaf buds, sugar and hydrocarbon metabolism and its transport, ribose nucleic acid (RNA) and indole acetic acid (IAA) metabolism, respiration, cytokinin production and transfer, and phenol metabolism are other functions influenced by $B$ in plants (Immanuel et al., 2019).

However, the proper micronutrient management, especially $B$, becomes essential for increases in crop yields, avoiding waste and possible toxicity. However, knowledge of the critical interval between the lower and upper limits for sunflower production is of fundamental importance in ensuring high and sustainable production (Flores et al., 2018; Viçosi et al., 2020). Therefore, this research aimed to evaluate the effect of boron application via soil on nutritional aspects and the biomass yield of Helianthus annuus.

\section{Results}

\section{Relative chlorophyll index $-\mathrm{RCl}$, height, and leaf area}

The biometric variables evaluated (leaf area and plant height) were influenced by the B doses in the soil, as shown in Table 1. However, after the polynomial regression analysis, a different behavior was observed for the two variables. In Fig 1a, it is possible to observe a linear increase in the leaf area of sunflower plants. With the highest dose, $4.0 \mathrm{~kg} \mathrm{ha}^{-1}$ of $\mathrm{B}$, the leaf area was around $31 \%$ higher than the treatment without the addition of boron. For the plant height, the best adjustment was quadratic behavior. The highest plant height $(108.64 \mathrm{~cm})$ was obtained with a dose of $2.29 \mathrm{~kg} \mathrm{ha}^{-1}$ of $\mathrm{B}$, about $8 \%$ higher than the control treatment (Fig 1b).

Regarding the assessments of the relative chlorophyll index $(\mathrm{RCl})$, there were significant effects only for assessments performed at 15 and 60 days after emergence (DAE) (Table 1). After the polynomial regression study, it is observed that there were linear adjustments for the $\mathrm{RCl}$ evaluated at 15 and $60 \mathrm{DAE}$, which reached 34.7 and 39.7, respectively, with the use of the highest dose. That is an increase of $12 \%$ in both evaluations concerning the control treatment (Fig 2).

\section{Biomass production and boron content}

All variables relative to biomass yield were influenced by the B application in the soil, as shown in Table 2. After studies of polynomial regression, linear behavior was observed in all variables evaluated, which reached $24.25 \mathrm{~g} \mathrm{plant}^{-1}$ of shoot dry matter, $1.46 \mathrm{~g} \mathrm{plant}^{-1}$ of root dry matter, $10.28 \mathrm{~g} \mathrm{plant}^{-1}$ of chapter dry matter, and $35.99 \mathrm{~g}^{\text {plant }}{ }^{-1}$ of total dry matter, with the use of the highest boron dose, which was around 51, 94, 90 and $61 \%$ higher than the treatment without B (Fig 3).

As an effect of the B application in the soil and, consequently, absorption by the plant increases nutrient content in the sunflower plant (Table 3). Without boron application, there was a higher boron content in the roots than the shoot, which was inverted with the boron application in the soil. The highest boron content in the shoot was observed with the use of $3.34 \mathrm{~kg} \mathrm{ha}^{-1}$ of $\mathrm{B}$, which reached $108 \mathrm{mg}$ plant $^{-1}$, about a 398\% increase when compared to the treatment without Boron. The content of $B$ in the roots did not show the same increase. Its absorption was linear, reaching $48.32 \mathrm{mg} \mathrm{kg}^{-1}$ with the use of the highest dose applied to the soil, that is, an increase of approximately $78 \%$ concerning the treatment without B addition (Fig 4a).

In Fig $4 b$, it is possible to observe a similar behavior between the boron accumulation in the shoot (BAS) and the whole plant (BAP). The data were adjusted to the quadratic polynomial regression model. The dose of $4.0 \mathrm{~kg} \mathrm{ha}^{-1}$ of boron provided the highest boron accumulation in the shoot ( $\left.2.50 \mathrm{mg} \mathrm{plant}^{-1}\right)$ and the plant (2.59 mg plant $\left.{ }^{-1}\right)$. The boron accumulation in the roots was adjusted to the linear model. The dose of $4.0 \mathrm{~kg} \mathrm{ha}^{-1}$ of boron represents a $250 \%$ increase in the micronutrient accumulation in the root system of sunflower plants compared to the treatment without boron.

\section{Absorption, transport, and use efficiency}

Table 4 shows that all efficiency parameters were influenced by the application of B to the soil. The transport and absorption efficiencies showed quadratic adjustments, which reached $98.55 \%$ and $2.10 \mathrm{mg} \mathrm{g}^{-1}$ of $\mathrm{B}$, using $2.46 \mathrm{~kg}$ ha1 (Fig 5a) and $2.76 \mathrm{~kg} \mathrm{ha}^{-1}$ of $B$ (Fig 5b), respectively. The boron use efficiency by sunflower plants (Fig $5 \mathrm{c}$ ) showed the opposite behavior to the other calculated efficiencies. The dose of $2.70 \mathrm{~kg} \mathrm{ha}^{-1}$ of boron results in the lowest micronutrient use efficiency of the plant $\left(342.21 \mathrm{mg} \mathrm{g}^{-1}\right.$ of boron).

\section{Discussion}

Fertilization with B was able to provide an increase in the biometric parameters of sunflower plants. However, the plant has a certain limit regarding the absorption, and consequently, the use by the plant. As can be seen at doses greater than $2.5 \mathrm{~kg} \mathrm{ha}^{-1}$ of $\mathrm{B}$, there are decreases in the plant height and their efficiency of absorption and transport of B. Similarly, in a study carried out by Al-Amery et al. (2011), it was observed that applications of $B$ in the soil up to the dose of $2.5 \mathrm{~kg} \mathrm{ha}^{-1}$ represented increases in leaf area and plant height of sunflower. Shehzad et al. (2016) found an increase in the sunflower leaf area at doses up to $3 \mathrm{~kg} \mathrm{ha}^{-1}$.

In a study by Capone et al. (2016), with three sunflower cultivars, the authors verified that maximum crop response 
was up to the application of $3 \mathrm{~kg} \mathrm{ha}^{-1}$ of $\mathrm{B}$ in the soil. In a recent study, Mehmood et al. (2018) observed that the $B$ application in the soil linearly increases the plant height and stem diameter; however, the dose with the maximum efficiency did not exceed $2 \mathrm{~kg} \mathrm{ha}^{-1}$.

Boron acts indirectly in the plant physiological activities; this function directly influences crop development (height, stem length, number of nodes, and leaf area), which favors greater interception and conversion of solar energy (Immanuel et al., 2019). This behavior is because B acts directly on the photosynthetic apparatus efficiency, thus increasing the net photosynthetic rate (Zahoor et al., 2011), and consequently, greater carbohydrates storage. Furthermore, boron has a major contribution to meristematic growth, cell division, stretching, cell wall stability, and binding of nitrogen synthesizers (Shehzad et al., 2016).

The relative chlorophyll index showed linear increments with the $B$ application at 15 and 60 DAE; that is, the plants presented darker green leaves with the greatest B supply. This behavior is related to the genetic crop traits or the better efficiency regarding the $\mathrm{N}$ use by the plant.

According to Flores et al. (2018), there is evidence of a positive relationship between the $\mathrm{N}$ content and the amount of $B$ absorbed by the plant. B acts directly on the synthesis of uracil, an RNA component. However, studies in the recent literature show a low correlation of B content in the plant with $\mathrm{RCl}$. Dhassi et al. (2019) and Khalid et al. (2020) reported that even in soils with low natural $B$ content, there was no significant response in $\mathrm{RCl}$ levels when evaluated in pre-flowering.

In the present study, the biomass production in all evaluated parts increased with the greater B supply in the soil. Gormus and Barutcular (2016) state that sunflower plants respond to the addition of up to $3 \mathrm{~kg} \mathrm{ha}^{-1}$ of $B$ in the soil. This behavior is because $B$ increases metabolic and photosynthetic activities, which promote the growth of young plant parts and, consequently, biomass (Sheoran et al., 2018).

There is evidence in the literature that the application of doses above $3 \mathrm{~kg} \mathrm{ha}^{-1}$ negatively influences sunflower growth. Bhattacharyya et al. (2015) report that, under the conditions evaluated, the application of lower doses than these are sufficient to correct the deficiency of B in the soil and that the application of high doses can cause phytotoxic effects on the plant, among them the reduction of growth and yield. Gormus and Barutcular (2016) stated that B toxicity is little reported, not affecting sunflower growth at doses that do not exceed $3 \mathrm{~kg} \mathrm{ha-1}$. Dhassi et al. (2019) indicate that one of the symptoms of boron phytotoxicity in sunflower may be the decline of shoot dry matter. In the present study, there was only a reduction in plant height at doses greater than $3 \mathrm{~kg} \mathrm{ha}^{-1}$, which may indicate the principle of disturbance in sunflower metabolism, which was not able to harm the biomass accumulation by the plant.

The increase in B content and accumulation in sunflower plants corroborates the results obtained in several studies carried out by Capone et al. (2016), Silva et al. (2016), Flores et al. (2018), Mehmood et al. (2018), and Khalid et al. (2020). The increase in boron levels in the soil increases its concentration in the leaves, even in high applied doses $(4 \mathrm{~kg}$ $\left.\mathrm{ha}^{-1}\right)$, since the surplus can be accumulated in their vegetative structures, especially in the leaves (Capone et al., 2016). Ekmekci et al. (2020) also report that sunflowers can absorb and accumulate $\mathrm{B}$, even at concentrations considered toxic in the soil (>0.9 $\mathrm{mg} \mathrm{dm}^{-3}$ ). Prezotti and Guarçoni 2013, demonstrated its high phytoextraction capacity, which can even be used to recover areas contaminated by micronutrients. Schiavon et al. (2018), when evaluating the rate of absorption of $B$ by the sunflower, they observed that the leaves are the compartment with the highest accumulation of $B$, up to 60 days after emergence.

As in the present study, Ekmekci et al. (2020) observed a greater B accumulation in the leaves and shoots than the roots. This effect can be attributed to the greater transport efficiency of the nutrient reached with the dose close to $3 \mathrm{~kg}$ $\mathrm{ha}^{-1}$. With the decrease in transport efficiency, there was a greater increase in the $\mathrm{B}$ content in the roots due to the $\mathrm{B}$ dose increase in the soil. Immanuel et al. (2019) observed that the greater availability of $B$ in the soil increased the sunflower root growth, promoting greater extraction of nutrients by the plant, which favored the greater shoot biomass production.

Boron participates in cell division and expansion processes, increasing the ability of the plant to penetrate deeper layers in search of water and nutrients (Trautmann et al., 2014). The reduction in $B$ absorption efficiency with lower doses than a $2.76 \mathrm{~kg} \mathrm{ha}^{-1}$ dose possibly occurred due to B toxicity on the roots, as no visual symptoms were observed in the shoot, which interferes with the nutrient acquisition (Krudnak et al., 2013).

The initial concentration of $B$ in the present study soil is considered low $\left(0.14 \mathrm{mg} \mathrm{dm}^{-3}\right)$ to produce sunflower in the soils of the Midwest region in Brazil. In this condition, the recommendation of fertilization of correction and production for the culture is of $2 \mathrm{~kg} \mathrm{ha}^{-1}$ (Sousa and Lobato, 2004). However, even with the application of $4.0 \mathrm{~kg} \mathrm{ha}^{-1}$, in other words, twice the amount recommended for the crop, sunflower plants did not show symptoms of B toxicity, which can be explained by the potential leaching effect promoted by irrigation and the high mobility of B in the soil. However, in the present study, the soil particle-size is considered clayey (>350 $\mathrm{g} \mathrm{kg}^{-1}$ of clay), limiting mobility in the soil profile, reducing leaching, and increasing the concentration of $B$ in the rhizosphere. Thus, because the ion-root contact is regulated by the mass flow (Prado, 2008), and the $B$ concentration in the rhizosphere region increases, the absorption process is favored (Jahiruddin et al., 2001).

The decision of whether or not to apply $B$ can also be based on leaf concentration, with sunflower contents varying between 35 and $100 \mathrm{mg} \mathrm{kg}^{-1}$, considered adequate by Sousa and Lobato (2004). Only the control treatment and the application of $4.0 \mathrm{~kg} \mathrm{ha}^{-1}$ of boron showed leaf contents outside the range considered appropriate for the crop. (21.70 and $103.50 \mathrm{mg} \mathrm{kg}^{-1}$, respectively).

The boron application to the soil affected its transport efficiency $\left(T R_{\text {ef }}\right)$ in sunflower plants, reaching $98.55 \%$ with the application of $2.46 \mathrm{~kg} \mathrm{ha}^{-1}$ of boron, occurring decrease with doses higher than $2.46 \mathrm{~kg} \mathrm{ha}^{-1}$. According to Uluisik et al. (2018), boron is absorbed by roots in the form of boric acid and sent to the xylem for transport to the shoot. This indicates that the transpiration flow controls its transport in plants, giving the element mobility in the xylem cells. This flow allows boron to be transported in the sunflower without any energy consumption occurring (Ekmekci et al., 2020). However, the micronutrient has a very narrow range as to its ideal level for plants, which may have a toxic effect and, consequently, reduced transport and accumulation in plant tissues (Bañón et al., 2012; Landi et al., 2019).

The maximum efficiency of absorption and transport of boron by sunflower plants was estimated with around $2.5 \mathrm{~kg}$ 
Table 1. Leaf area, plant height, and relative chlorophyll index ( $\mathrm{RCl})$ of Helianthus annuus plants according to the boron application in the soil.

\begin{tabular}{|c|c|c|c|c|c|c|}
\hline $\begin{array}{l}\text { Boron } \\
\text { doses }\end{array}$ & Leaf area & Height & $\mathrm{RCl}^{1}$ & $\mathrm{RCl}^{2}$ & $\mathrm{RCl}^{3}$ & $\mathrm{RCl}^{4}$ \\
\hline $\mathrm{kg} \mathrm{ha}^{-1}$ & $\mathrm{~cm}^{2}$ & $\mathrm{~cm}$ & \multicolumn{4}{|c|}{ - } \\
\hline 0 & $316.05 \pm 3.22$ & $100.50 \pm 1.04$ & $30.46 \pm 0.78$ & $31.52 \pm 0.20$ & $33.42 \pm 0.30$ & $34.96 \pm 0.48$ \\
\hline 1.0 & $346.44 \pm 8.73$ & $106.25 \pm 0.63$ & $32.30 \pm 0.45$ & $31.60 \pm 0.36$ & $34.67 \pm 0.64$ & $38.01 \pm 0.51$ \\
\hline 2.0 & $354.79 \pm 6.37$ & $107.50 \pm 1.04$ & $33.35 \pm 0.44$ & $32.41 \pm 0.32$ & $33.39 \pm 0.13$ & $37.05 \pm 0.96$ \\
\hline 3.0 & $398.42 \pm 14.38$ & $109.00 \pm 0.41$ & $34.13 \pm 0.89$ & $32.89 \pm 0.67$ & $33.69 \pm 0.55$ & $38.15 \pm 0.24$ \\
\hline 4.0 & $414.39 \pm 13.32$ & $103.75 \pm 0.63$ & $34.10 \pm 0.48$ & $32.34 \pm 0.56$ & $33.44 \pm 0.09$ & $39.98 \pm 1.09$ \\
\hline F-test & $15.63^{* *}$ & $17.93 * *$ & $5.85^{* *}$ & $1.63^{\mathrm{ns}}$ & $1.78^{\mathrm{ns}}$ & $6.31^{* *}$ \\
\hline C.V. (\%) & 5.53 & 1.50 & 3.87 & 2.82 & 2.42 & 3.88 \\
\hline
\end{tabular}

$1,2,3$, and ${ }^{4}$ - evaluation at $15,30,45$, and 60 days after emergence, respectively. ${ }^{* *}$ significant at $1 \%$ probability by the $\mathrm{F}$ test. ${ }^{\text {ns }}$ non-significant by the $\mathrm{F}$-test.
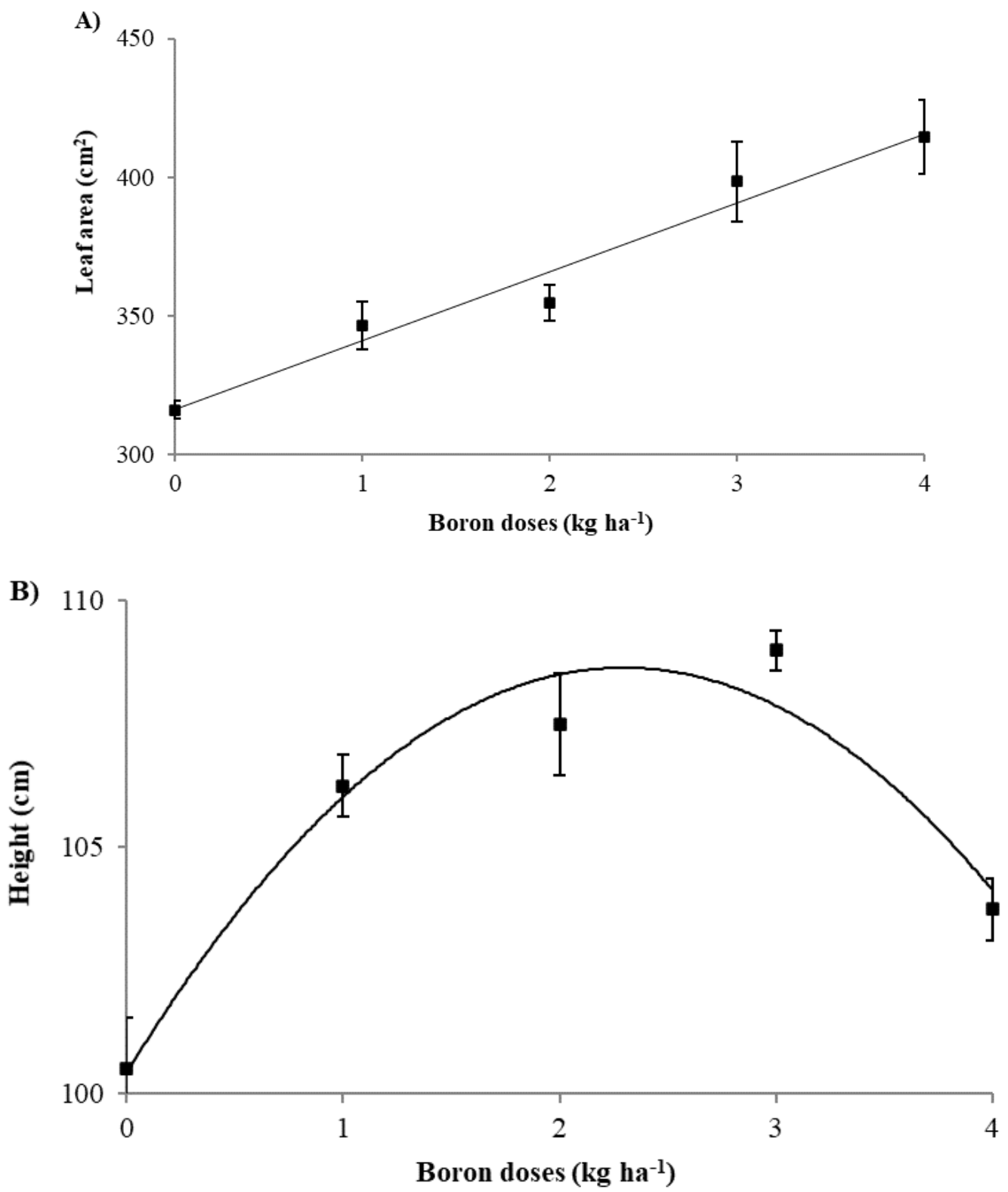

Fig 1. Leaf area (A) and plant height (B) of Helianthus annuus plants according to the boron application in the soil. Leaf area: $y=24.866 x+316.29$; $R^{2}=0.97 ; F=60.45^{*} ;$ Height: $y=-1.5536 x^{2}+7.1393 x+100.44 ; R^{2}=0.94 ; F=54.06^{*}$.

* significant at $5 \%$ probability by the $\mathrm{F}$ test. 
Table 2. Shoot dry matter (SDM), root dry matter (RDM), chapter dry matter (CDM), and entire plant dry matter (EPDM) of Helianthus annuus plants according to the boron application in the soil.

\begin{tabular}{|c|c|c|c|c|}
\hline $\begin{array}{c}\text { Boron doses } \\
\text { kg ha }{ }^{-1}\end{array}$ & \multicolumn{3}{c|}{ RDM } & \multicolumn{2}{c|}{ CDM } \\
\hline 0 & $16.00 \pm 0.82$ & $0.75 \pm 0.03$ & $5.41 \pm 0.43$ & $22.16 \pm 0.70$ \\
\hline 1.0 & $18.00 \pm 0.91$ & $0.83 \pm 0.10$ & $6.85 \pm 0.39$ & $25.68 \pm 1.18$ \\
\hline 2.0 & $20.50 \pm 0.65$ & $1.03 \pm 0.07$ & $8.65 \pm 0.32$ & $30.18 \pm 0.46$ \\
\hline 3.0 & $21.75 \pm 0.25$ & $1.06 \pm 0.03$ & $9.32 \pm 0.26$ & $32.13 \pm 0.37$ \\
\hline 4.0 & $24.25 \pm 0.63$ & $1.46 \pm 0.14$ & $10.28 \pm 0.67$ & $35.99 \pm 1.28$ \\
\hline F-test & $21.75^{* *}$ & $10.30^{* *}$ & $19.84^{* *}$ & $37.85^{* *}$ \\
\hline C.V. (\%) & 6.86 & 16.66 & 10.84 & 6.03 \\
\hline
\end{tabular}

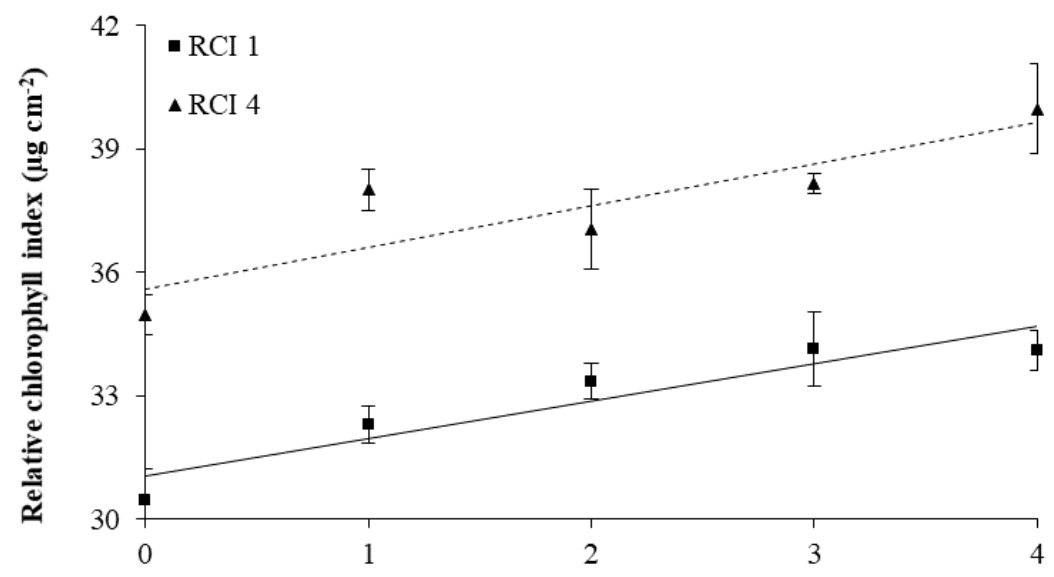

Boron doses $\left(\mathrm{kg} \mathrm{ha}^{-1}\right)$

Fig 2. Relative chlorophyll index of Helianthus annuus at $15(\mathrm{RCl} 1)$ and $60(\mathrm{RCl} 4)$ days after emergence (DAE) plants according to the boron application in the soil. $\mathrm{RCl} 1: \mathrm{y}=0.911 \mathrm{x}+31.046 ; \mathrm{R}^{2}=0.88 ; \mathrm{F}=20.52^{* *} ; \mathrm{RCl} 2: \mathrm{y}=1.018 \mathrm{x}+35.594 ; \mathrm{R}^{2}=0.77 ; \mathrm{F}=19.50^{* *}$.

** significant at $1 \%$ probability by the $\mathrm{F}$ test.

Table 3. Boron content in the shoot and roots and boron accumulation of boron in shoot, roots, and entire plant of Helianthus annuus according to the application of boron in the soil.

\begin{tabular}{|c|c|c|c|c|c|}
\hline \multirow[t]{2}{*}{ Boron doses } & \multicolumn{2}{|c|}{------------Content---------- } & \multicolumn{3}{|c|}{----1, } \\
\hline & Shoot & Root & Shoot & Root & Entire plant \\
\hline $\mathrm{kg} \mathrm{ha}^{-1}$ & \multicolumn{2}{|c|}{----------mg kg-1---------- } & \multicolumn{3}{|c|}{ 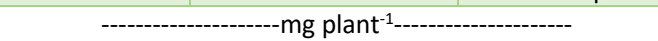 } \\
\hline 0 & $21.70 \pm 3.15$ & $27.12 \pm 0.26$ & $0.35 \pm 0.055$ & $0.020 \pm 0.001$ & $0.37 \pm 0.054$ \\
\hline 1.0 & $67.39 \pm 2.49$ & $29.05 \pm 0.17$ & $1.21 \pm 0.066$ & $0.024 \pm 0.065$ & $1.23 \pm 0.065$ \\
\hline 2.0 & $92.85 \pm 3.27$ & $36.74 \pm 0.88$ & $1.90 \pm 0.086$ & $0.037 \pm 0.002$ & $1.94 \pm 0.084$ \\
\hline 3.0 & $99.36 \pm 1.94$ & $39.68 \pm 0.21$ & $2.16 \pm 0.033$ & $0.042 \pm 0.001$ & $2.20 \pm 0.034$ \\
\hline 4.0 & $103.50 \pm 1.55$ & $48.32 \pm 0.89$ & $2.51 \pm 0.082$ & $0.070 \pm 0.007$ & $2.58 \pm 0.087$ \\
\hline F-test & $174.71 * *$ & $214.52 * *$ & $162.95 * *$ & $31.05^{* *}$ & $166.83^{* *}$ \\
\hline C.V. (\%) & 6.67 & 3.23 & 8.27 & 18.26 & 8.14 \\
\hline
\end{tabular}

** significant at $1 \%$ probability by the F-test.

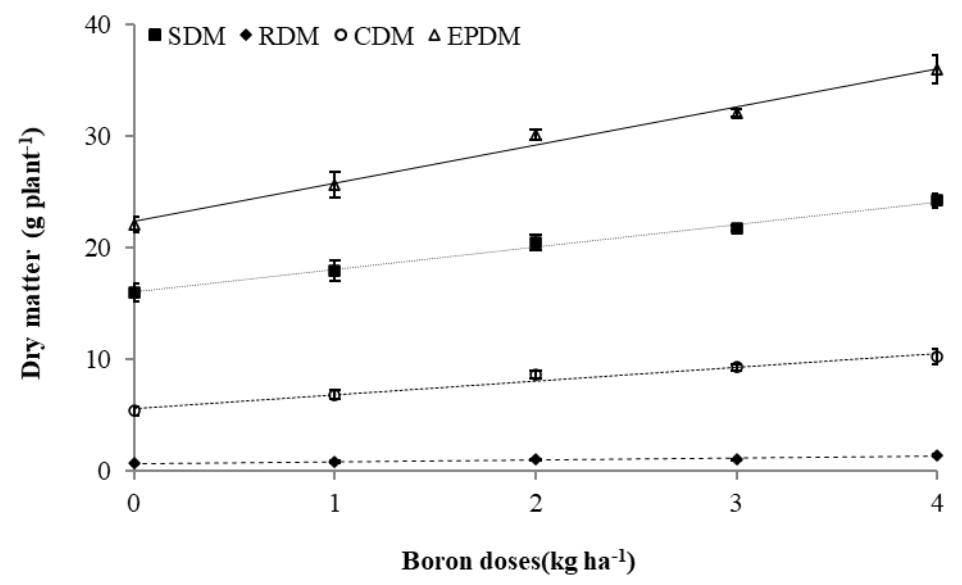

Fig 3. Shoot dry matter (SDM), root dry matter (RDM), chapter dry matter (CDM), and entire plant dry matter (EPDM) of Helianthus annuus plants according to the boron application in the soil. SDM: $y=2.025 x+16.05 ; R^{2}=0.99 ; F=86.33^{* *} . R D M: y=1.221 x+5.66 ; R^{2}=0.97 ; F=77.08^{* *}$. CDM: $y=0.165 x+0.696 ; R^{2}=0.89 ; F=36.79 * *$. EPDM: $y=3.411 x+22.406 ; R^{2}=0.98 ; F=149.82 * *$.

$* *$ significant at $1 \%$ probability by the $\mathrm{F}$ test. 
Table 4. Boron transport efficiency (BTR $\mathrm{ef}$ ), boron absorption efficiency $\left(\mathrm{AB}_{\mathrm{ef}}\right)$, and boron use efficiency ( $\left.\mathrm{U}_{\mathrm{ef}}\right)$ of Helianthus annuus plants according to the boron application in the soil.

\begin{tabular}{|c|c|c|c|}
\hline $\begin{array}{c}\text { Boron doses } \\
\mathrm{kg} \mathrm{ha}^{-1}\end{array}$ & T & \multicolumn{2}{|c|}{$\mathrm{AB}_{\text {ef }}$} \\
\hline 0 (control) & $93.93 \pm 1.19$ & $0.49 \pm 0.082$ & $1,416.40 \pm 188.71$ \\
\hline 1.0 & $97.98 \pm 0.35$ & $1.55 \pm 0.199$ & $535.01 \pm 27.16$ \\
\hline 2.0 & $98.04 \pm 0.17$ & $1.93 \pm 0.206$ & $472.09 \pm 21.92$ \\
\hline 3.0 & $98.08 \pm 0.05$ & $2.07 \pm 0.058$ & $469.63 \pm 13.27$ \\
\hline 4.0 & $97.26 \pm 0.22$ & $1.80 \pm 0.218$ & $501.97 \pm 19.29$ \\
\hline F-test & $9.83^{* *}$ & $17.02 * *$ & $22.82 * *$ \\
\hline C.V. $(\%)$ & 1.17 & 19.52 & 25.47 \\
\hline
\end{tabular}

** significant at $1 \%$ probability by the $\mathrm{F}$-test.
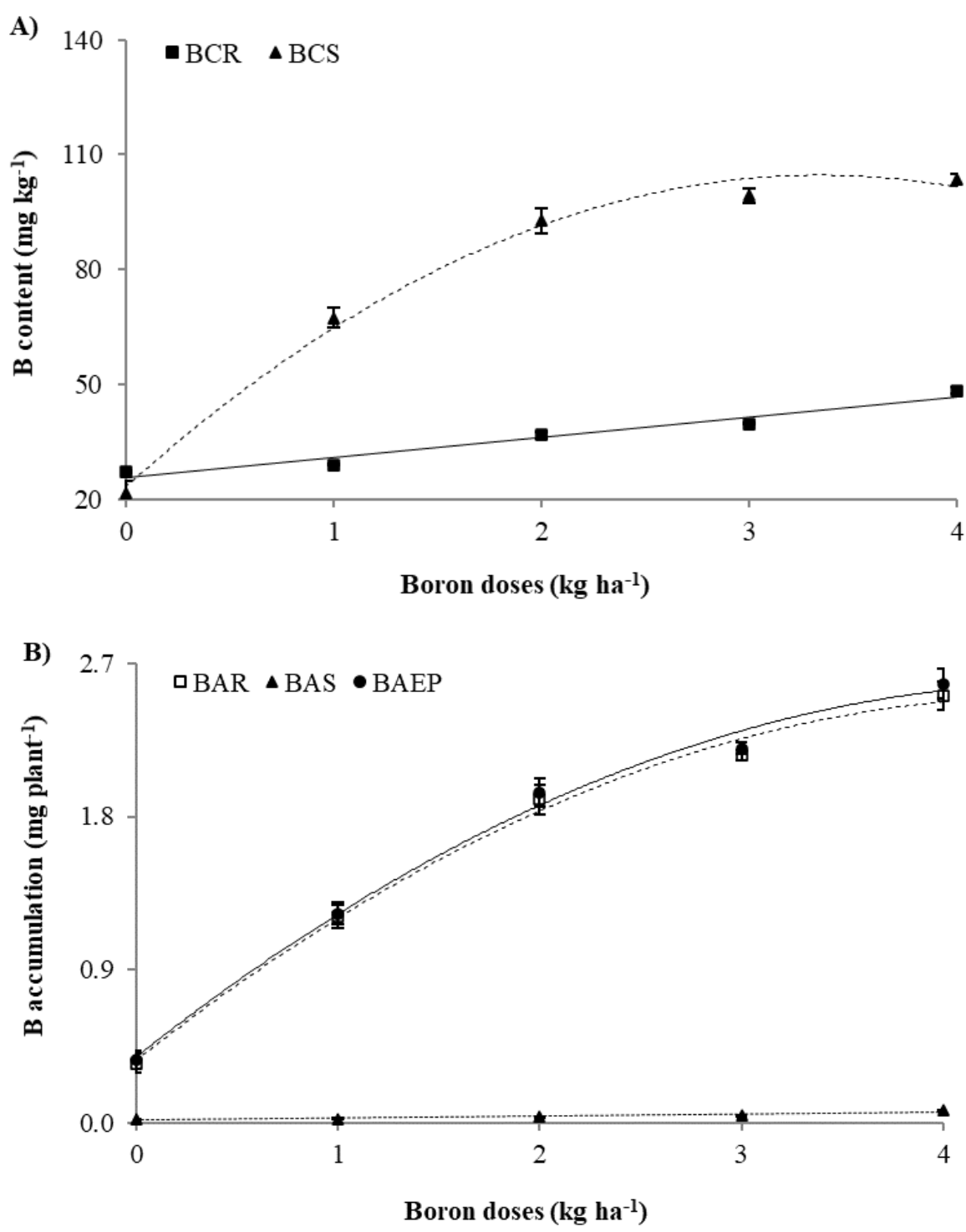

Fig 4. Boron content $(A)$ in the roots $(B C R)$ and shoot (BCS), and Boron accumulation (B) in the shoots (BAS), roots (BAR) e entire plant (BAEP) of Helianthus annuus plants according to the application of boron in the soil. A) $B C R: y=5.3013 x+25.582 ; R^{2}=0.96 ; F=19.07 * ; B C S: y=-7.2896 x^{2}+$ 48.715x + 23.269; $\left.R^{2}=0.99 ; F=48.79 * ; B\right) B A S: y=-0.1036 x^{2}+0.9413 x+0.3649 ; R^{2}=0.99 ; F=33.70 * ; B A R: y=0.0118 x+0.015 ; R^{2}=0.893 ; F=$ 9.47*; BAEP: $y=-0.1007 x^{2}+0.9419 x+0.3846 ; R^{2}=0.99 ; F=31.32 *$.

$*$ significant at $5 \%$ probability by the $\mathrm{F}$ test. 

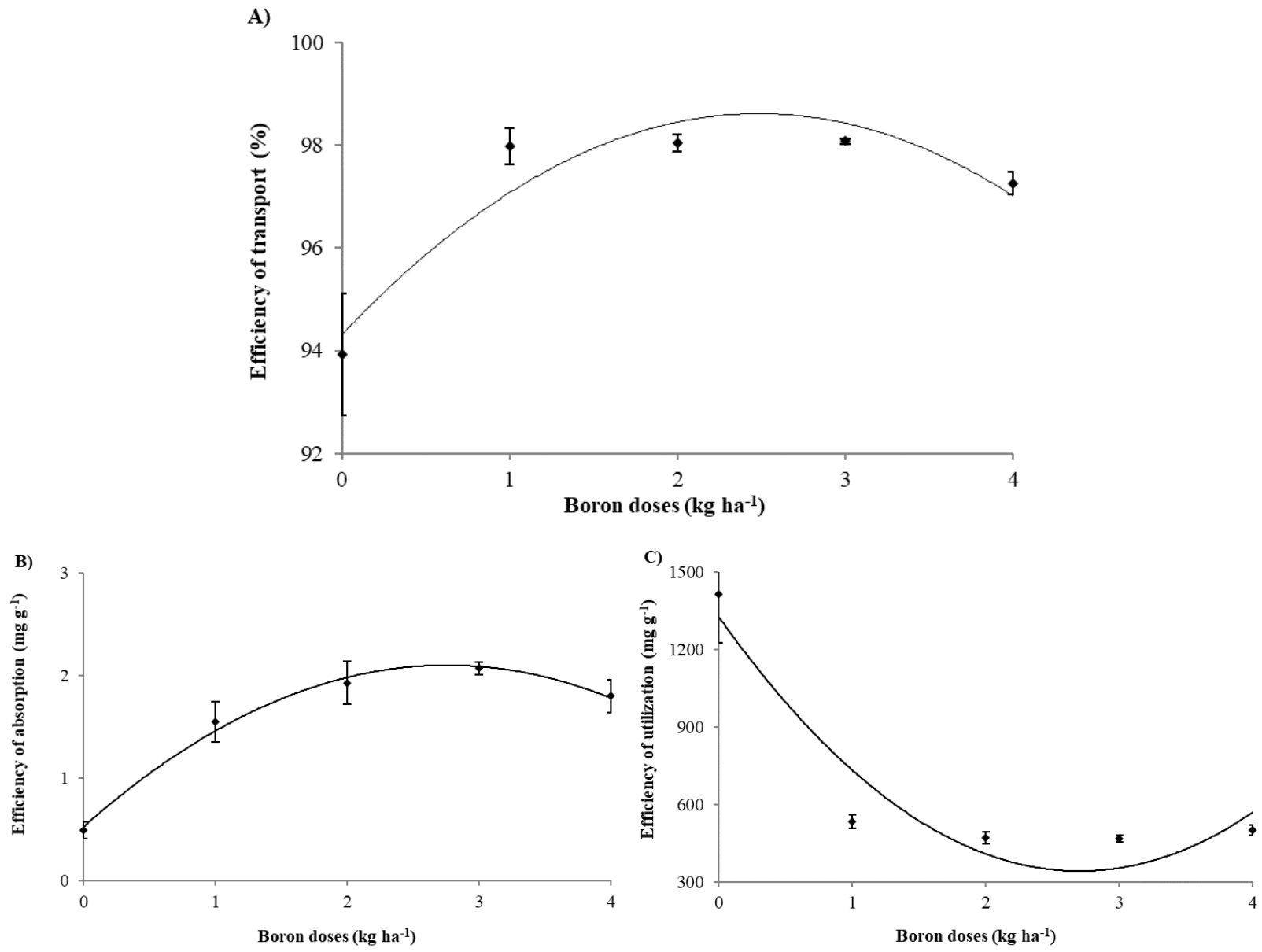

Fig 5. Boron efficiency of transport (TRef) (A), efficiency of absorption ( $\left.A B_{\mathrm{ef}}\right)(\mathrm{B})$, and boron efficiency of utilization ( $\mathrm{U}_{\mathrm{ef}}$ ) (C) of Helianthus annuus plants according to the boron application in the soil. TRef: $y=-0.6971 x^{2}+3.446 x+94.312 ; R^{2}=0.8967 ; F=21.07 * A B_{\text {ef: }} y=-0.2071 x^{2}+1.1426 x+$ $0.5257 ; R^{2}=0.9921 ; F=25.37^{*} ; U_{\text {ef: }} y=134.85 x^{2}-728.83 x+1327.6 ; R^{2}=0.90 ; F=34.06^{*}$. * significant at $5 \%$ probability by the $F$ test.

$\mathrm{ha}^{-1}$, with a subsequent reduction in the efficiency. Efficiency in the use of nutrients is complex, as it is linked to the crop capacity to absorb nutrients from the soil, carry out transport, store, and mobilize when necessary (Immanuel et al., 2019).

The reduction in the boron use efficiency with the increase in the applied dose is reported by Flores et al. (2018), which states that the micronutrient ability to use and its conversion into biomass decreases with increasing plant absorption. Bhattacharyya et al. (2015) observed that increasing fertilization with $B$ at doses greater than $2 \mathrm{~kg} \mathrm{ha}^{-1}$ via soil reduced the efficiency of using sunflower $B$. When the nutrient use efficiency is reduced; plants need larger amounts to produce one gram of dry matter; that is, the greater its absorption of the nutrient, the lower its conversion into biomass, and the lower its efficiency, which can result in higher production cost (Flores et al., 2017; Flores et al., 2019). Thus, there is a deleterious effect, both in the efficiency of absorption and transport, and in the efficiency of use, with an increase in the applied boron dose.

\section{Materials and Methods}

Location and characteristics of the experimental area The study was carried out in a greenhouse at the School of Agronomy of the Federal University of Goiás, State of Goiás,
Brazil, at $16^{\circ} 35^{\prime} 12^{\prime \prime} \mathrm{S}, 49 \circ 21^{\prime} 14^{\prime \prime} \mathrm{W}$. The climate of the region is Aw type according to the Köppen classification (Cardoso et al., 2014), with dry winter and rainy summers. The greenhouse temperature during the plant growth and the experiment was around $32 \pm 3{ }^{\circ} \mathrm{C}$ during the day, and 26 $\pm 3^{\circ} \mathrm{C}$ during the night.

The previous chemical analysis of the soil was carried out according to procedures proposed by Teixeira et al. (2017), and presented the following properties: $\mathrm{pH}: 4.4\left(\mathrm{CaCl}_{2}\right)$; organic matter: $2.3 \mathrm{~g} \mathrm{dm}^{-3} ; \mathrm{P}: 0.8 \mathrm{mg} \mathrm{dm}^{-3} ; \mathrm{K}^{+}: 25 \mathrm{mg} \mathrm{dm}^{-3}$. $\mathrm{Ca}^{2+}: 0.4 \mathrm{cmol}_{\mathrm{c}} \mathrm{dm}^{-3} ; \mathrm{Mg}^{2+}: 0.3 \mathrm{cmol}_{\mathrm{c}} \mathrm{dm}^{-3} ; \mathrm{SO}_{4}{ }^{2-}: 5.6 \mathrm{mg} \mathrm{dm}$ 3; Zn: $1.4 \mathrm{mg} \mathrm{dm}^{-3}$; B: $0.14 \mathrm{mg} \mathrm{dm}^{-3}$; $\mathrm{Al}^{3+}: 0.5 \mathrm{cmol}_{\mathrm{c}} \mathrm{dm}^{-3}$; $\mathrm{H}+\mathrm{Al}^{3+}: 1.27 \mathrm{cmol}_{\mathrm{C}} \mathrm{dm}^{-3}$; cation exchange capacity (CEC): 2.03 $\mathrm{cmol}_{\mathrm{c}} \mathrm{dm}^{-3}$; base saturation (V\%): $37.4 \%$. The soil granulometric analysis showed 530, 180 and $135 \mathrm{~g} \mathrm{~kg}^{-1}$ of clay, silt, and sand, respectively.

\section{Treatments and experimental design}

A completely randomized design with four replications was used. Five boron doses: 0 (control), 1, 2, 3, and $4 \mathrm{~kg} \mathrm{ha}^{-1}$, applied to the soil using boric acid as the source $(17 \%$ de $B$, solubility in water: $\left.63 \mathrm{~g} \mathrm{~L}^{-1}\right)$, were evaluated. Each experimental plot consisted of a pot $\left(4 \mathrm{dm}^{3}\right)$ filled with 3.5 $\mathrm{dm}^{3}$ of soil from the $0-0.20 \mathrm{~m}$ layer. The soil is classified as a Rhodic Hapludox (Soil-Survey-Staff, 2014). 


\section{Experiment development}

The soil correction for the neutralization of exchangeable aluminum and elevation of the calcium and magnesium contents was carried out considering the increase of base saturation to $60 \%$ (Sousa and Lobato, 2004). Dolomitic limestone was applied ( $\mathrm{CaO}=36 \% ; \mathrm{MgO}=15 \% ; \mathrm{PN}=98 \%$; PRNT=92.54\%), keeping the soil mass moist $(60 \%$ of the water retention capacity of soil), incubated for 30 days, to occur the limestone reaction with the soil (Pádua et al., 2006).

For planting fertilization, $50 \mathrm{~mL}$ per pot of a nutrient solution containing $1.5 \mathrm{mg} \mathrm{dm}^{-3}$ of $\mathrm{Cu}\left(\mathrm{CuSO}_{4} .5 \mathrm{H}_{2} \mathrm{O}\right.$ p.a.), $0.15 \mathrm{mg} \mathrm{dm}^{-}$ 3 of $\mathrm{Mo}\left(\mathrm{NaMoO}_{4} \cdot 2 \mathrm{H}_{2} \mathrm{O}\right.$ p.a.), $4.0 \mathrm{mg} \mathrm{dm}-3$ of $\mathrm{Fe}\left[\mathrm{Fe}_{2}\left(\mathrm{SO}_{4}\right)_{3}\right.$. $4 \mathrm{H}_{2} \mathrm{O}$ p.a.], and $5.0 \mathrm{mg} \mathrm{dm}^{-3}$ of $\mathrm{Zn}\left(\mathrm{ZnSO}_{4}\right.$ p.a.) was applied to the soil surface contained in the pots. Also, the following macronutrient doses were applied to the soil: $110 \mathrm{~kg} \mathrm{ha}^{-1}$ of $\mathrm{P}_{2} \mathrm{O}_{5}$ (simple superphosphate), $60 \mathrm{~kg} \mathrm{ha}^{-1}$ of $\mathrm{K}_{2} \mathrm{O}(\mathrm{KCl})$, and $120 \mathrm{~kg} \mathrm{ha}^{-1}$ of $\mathrm{N}$ (urea). Part of $\mathrm{N}$ fertilization was applied at sowing (20 kg ha-1 de $\mathrm{N}$ ). The rest was divided into two applications of $50 \mathrm{~kg} \mathrm{ha}^{-1}$ at 20 and 40 days after sowing, respectively, as indicated by Sousa and Lobato (2004). Boron doses were applied to the soil surface and incorporated at $10 \mathrm{~cm}$ depth immediately after the plant emergence.

Planting was performed on 27/06/2018, using the Altis 99 sunflower hybrid (Helianthus annuus) obtained in the winter season of 2017. Ten days after emergence (DAE), thinned was performed, leaving two viable and healthy plants per pot. Irrigation was performed with distilled and deionized water by weighing the pots, maintaining the humidity corresponding to $60 \%$ of the soil water retention capacity.

Relative chlorophyll index $-\mathrm{RCl}$, plant height, and leaf area The evaluations of the relative chlorophyll index were performed in the third expanded leaf of each plant, according to procedures proposed by Castro et al. (2019), with the aid of the chlorophyll meter FALKER ClorofiLOG model CFL1030. The determination of the RCl was made in four moments: $1 / 3$ of the vegetative stage (15 DAE), half of the vegetative stage (30 DAE), end of the vegetative stage, in pre-flowering (45 DAE), and at the time of harvest (60 DAE). At the harvest, the plant height (distance from the base to the last leaf insertion) was evaluated. The leaf area was also evaluated with the aid of the leaf area integrator model LI3100 Area Meter.

\section{Biomass production and boron content determination}

The harvest was then carried out, separating the aerial part, chapter, and roots of the sampled plants. The plant tissue samples were properly washed in a $0.1 \%$ detergent solution, $0.3 \%$ acid solution, and distilled water, to eliminate possible residues. Then they were placed in a forced-air circulation oven ( $65{ }^{\circ} \mathrm{C}, 48$ hours) to stabilize its dry weight and determine the dry biomass of each part. The boron levels in each part were determined according to the method described by Silva et al. (2009). Then, Boron accumulation was calculated from the $B$ content in each part of the plant and the dry biomass amount.

\section{Absorption, transport, and use efficiency}

From the dry matter and content of nutrients in plants data, the calculation of the following nutritional indexes was estimated: boron absorption efficiency $\left(A B_{\text {ef }}\right)$, Equation 1 (Swiader et al., 1994), boron transport efficiency ( $T_{\mathrm{ef}}$ ), Equation 2 (Li et al., 1991), and boron use efficiency for conversion to dry matter (UT ef), Equation 3 (Siddiqi and Glass, 1981). The estimation of these indexes was according to below:

Equation 1:

Equation 2:

$$
\mathrm{AB}_{\mathrm{ef}}=\frac{\text { total nutrient content in plant }}{\text { root dry matter }}
$$

Equation 3

$$
\mathrm{TR}_{\mathrm{ef}}=\frac{\text { (total nutrient content in the shoot) }}{\text { (total nutrient content in the plant) }} \times 100
$$

\section{Statistical analysis}

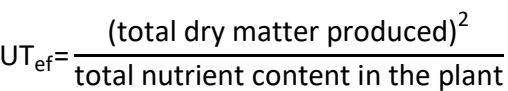

The results obtained were subjected to analysis of variance by the F-test, using the AgroEstat software (Barbosa and Maldonado Júnior, 2015), and then, polynomial regression analysis was applied. Linear and quadratic mathematical models were tested, applying the best fit to the data, adopting a criterion for choosing the model the magnitude of the significant regression coefficients at $5 \%$ probability by the t-test.

The maximum points were calculated by deriving the significant equations. For all variables studied, the standard error of the sample mean $(\mathrm{s} / \mathrm{Vn})$ was calculated, which: $s$ corresponds to the standard deviation, and $n$, the number of observations in the sample (Lunet et al., 2006).

\section{Conclusion}

Boron fertilization in sunflower crop positively influences the nutritional and growth aspects of plants. In general, the application of up to $3 \mathrm{~kg} \mathrm{ha}^{-1}$ of $B$ in soils with a low natural level $\left(<0.20 \mathrm{mg} \mathrm{dm}^{-3}\right)$ increases the sunflower yield, with non-expressing phytotoxicity aspects caused by the nutrient.

\section{References}

Al-Amery M, Hamza J, Fuller M (2011) Effect of boron foliar application on reproductive growth of sunflower (Helianthus annuus L.). Int J Agron. Article ID 230712.

Alves LS, Stark EMLM, Zonta E, Fernandes MS, Santos AMd, Souza SRd (2017) Different nitrogen and boron levels influence the grain production and oil content of a sunflower cultivar. Acta Sci Agron. 39(1):59-66.

Bañón S, Miralles J, Ochoa J, Sánchez-Blanco M (2012) The effect of salinity and high boron on growth, photosynthetic activity and mineral contents of two ornamental shrubs. Hort Sci. 39(4):188-194.

Barbosa JC, Maldonado Júnior W (2015) Experimentação agronômica \& Agroestat - Sistema para análises de ensaios agronômicos, 1 th. Funep.

Bhattacharyya K, Mandal J, Banerjee H, Alipatra A, Ray K, Phonglosa A (2015) Boron Fertilization in Sunflower (Helianthus annuus L.) in an Inceptisol of West Bengal, India. Commun Soil Sci.Plant Anal. 46(4):528-544.

Camacho-Cristóbal JJ, Rexach J, González-Fontes A (2008) Boron in plants: deficiency and toxicity. J Integr Plant Biol. 50(10):1247-1255.

Campos JO, Chaves HML (2020) Trends and Variabilities in the Historical Series of Monthly and Annual Precipitation in Cerrado Biome in the Period 1977-2010. Rev Bras Meteorol. 35(1):157-169.

Capone A, Dario AS, Menegon MZ, Fidelis RR, Barros HB (2016) Responses of sunflower cultivars to increasing doses of boron in the between harvests the Cerrado 
Tocantinense. Rev Verde Agroecologia Desenvolv Sustent. 11(1):43-48.

Cardoso MRD, Marcuzzo FFN, Barros JR (2014) Classificação climática de Köppen-Geiger para o estado de Goiás e o Distrito Federal. Acta Geogr. 8(16):40-55.

Castro GF, Ferreira JA, Zotarelli L, Mattiello EM, Novais RF, Tronto J (2019) Layered double hydroxides intercalated with borate: effect of fertilization on boron leaching and successive sunflower cultivations. New J Chem. DOI: 10.1039/c9nj04952e.

Das R, Mandal B, Sarkar D et al (2019) Boron availability in soils and its nutrition of crops under long-term fertility experiments in India. Geoderma. 351(1):116-129.

Dhassi K, Drissi S, Makroum K, Nasreddine F, Amlal F, Houssa AA (2019) Effects of Boron Fertilization on Sunflower Grown on Low Boron Sandy Soil. ST-JSSA. 16(1):67-75.

Ekmekci Y, Erdal ŞÇ, Nalçaiyi ASB, Çiçek N (2020) Acquisition of boron tolerance by salt pretreatment in two sunflower cultivars. Turk J Bot. 44(2):153-166.

Euba Neto M, Fraga VdS, Dias BdO, Souto JS (2014) Efeito de doses de boro no crescimento vegetativo de girassol em diferentes classes de solos. Rev Ceres. 61(3):399-405.

Flores RA, Arruda EM, Souza Junior JP et al (2019) Nutrition and production of Helianthus annuus in a function of application of leaf silicon. J plant nutr. 42(2):137-144.

Flores RA, Silva Junior AR, Damin V, Arruda EM, Prado ER, Araújo CE (2017) Nutrition and production of Phaseolus vulgaris (BRS Estilo) following boron application on soil. Commun Soil Sci Plant Anal. 48(12):1409-1416.

Flores RA, Silva TV, Damin V, Marques Carvalho RdC, Pereira DRM, Souza Junior JPd (2018) Common bean productivity following diverse boron applications on soil. Commun Soil Sci Plant Anal. 49(6):725-734.

Gomes EP, Fedri G, Avila MR, Biscaro GA, Rezende RK, Jordan RA (2012) Grain yield, oil and dry matter of sunflower under different depths of supplementary irrigation. Rev Bras Eng Agríc Ambient. 16(3):237-246.

Gormus O, Barutcular C (2016) Boron Nutrition Studies with Cotton and Sunflower in Southern Turkey. Commun Soil Sci Plant Anal. 47(7):915-929.

Immanuel RR, Saravanan D, Rao GS, Thiruppathi M, Saravanaperumal M (2019) Zinc and boron micronutrient fertilization on the growth and physiological attributes of sunflower in rice-sunflower cropping sequence. Plant Archives. 19(2):3015-3020.

Jahiruddin M, Harada H, Hatanaka T, Sunaga Y (2001) Adding boron and zinc to soil for improvement of fodder value of soybean and corn. Commun Soil Sci Plant Anal. 32(1718):2943-2951.

Kaleri A, Laghari G, Gandahi AW, Kaleri A, Nizamani MM (2019) Integrated foliar fertilizer effects on growth and yield of sunflower. Pak J.Agri, Agril Engg, Vet Sci. 35(1):2528.

Khalid D, Saad D, Kacem M, Ezzahra NF, Fouad A, Abdelhadi $\mathrm{AH}$ (2020) Sunflower response to Boron supply when grown in a silty clay soil. J Saudi Soc Agric Sci. 19(1):81-86.

Krudnak A, Wonprasaid S, Machikowa T (2013) Boron affects pollen viability and seed set in sunflowers. Afr J Agric Res. 8(2):162-166.

Landi M, Margaritopoulou T, Papadakis IE, Araniti F (2019) Boron toxicity in higher plants: an update. Planta. 250: 122.

Li Y, Hagen G, Guilfoyle TJ (1991) An auxin-responsive promoter is differentially induced by auxin gradients during tropisms. Plant Cell. 3(11):1167-1175.
Lunet N, Severo M, Barros H (2006) Desvio padrão ou erro padrão. Arq Med. 20(1):55-59.

Mehmood A, Saleem MF, Tahir M, Sarwar MA, Abbas T, Zohaib A, Abbas HT (2018) Sunflower (Helianthus annuus L.) growth, yield and oil quality response to combined application of nitrogen and boron. Pak J Agric Sci. 31(1):8697.

Öztürk Ö, Ceyhan E, Önder M, Harmankaya M, Hamurcu M, Gezgin S (2010) Micronutrient contents in leaves of sunflower cultivars grown with different boron doses. Helia. 33(53):215-220.

Pádua TRP, Silva CA, Melo LCA (2006) Calagem em Latossolo sob influência de coberturas vegetais: neutralização da acidez. Rev Bras Ciênc Solo. 30(5):869-878.

Penereiro JC, Ferreira DHL, Badinger A (2020) Tendências de insolação, temperatura média e precipitação nos máximos do inverno e verão no Brasil. Acta Geogr. 14(34):54-73.

Prado RM (2008) Plant Nutrition. UNESP, São Paulo.

Prezotti LC, Guarçoni AM (2013) Guia de interpretações de análise de solo e foliar. Incaper, Vitória.

Schiavon NC, Lima RC, Aguiar VF, Santos VKS, Pereira GAM, Silva EB, Ferreira EA (2018) Marcha de absorção de nutrientes em plantas de girassol (Helianthus annuus). Cult Agron. 27(2):236-250.

Shehzad MA, Maqsood M, Wajid SA, Anwar-ul-Haq M (2016) Dry matter partitioning and mineral constitution response of sunflower (Helianthus annuus) to integrated nitrogen and boron nutrition in calcareous soils. Int J Agric Biol. 18(2):257-265.

Sheoran P, Sardana V, Chander S, Kumar A, Meena M, Bali A, Sharma P (2018) Sulphur, boron and zinc nutrition to improve productivity, profitability and oil quality in sunflower (Helianthus annuus). Indian J Agric Sci. 88(11):1746-1754

Siddiqi MY, Glass AD (1981) Utilization index: a modified approach to the estimation and comparison of nutrient utilization efficiency in plants. J Plant Nutr. 4(3):289-302.

Silva FC (ed) (2009) Manual de análises químicas de solos, plantas e fertilizantes. Embrapa Informação Tecnológica, Brasília.

Silva FDB, Aquino LA, Panozzo LE, Lima TC, Berger PG, Dias DCFS (2016) Influence of boron on sunflower yield and nutritional status. Commun Soil Sci Plant Anal. 47(7):809817.

Soil-Survey-Staff (2014) Keys to soil taxonomy. USDA-Natural Resources Conservation Service, Washington.

Sousa DMG de, Lobato E (2004) Cerrado: Correction of soil and fertilization. Embrapa Cerrados, Planaltina.

Souza A, de Oliveira MF, Castiglioni VBR (2004) The boron on sunflower crop. Semin Ciênc Agrár. 25(1):27-34.

Swiader J, Chyan Y, Freiji F (1994) Genotypic differences in nitrate uptake and utilization efficiency in pumpkin hybrids. J Plant Nutr. 17(10):1687-1699.

Tahir M, Younasishaq M, Sheikh A, Naeem M, Rehman A (2014) Effect of boron on yield and quality of sunflower under agro-ecological conditions of Faisalabad (Pakistan). Sci Agric. 7(1):19-24.

Teixeira PC, Donagemma GK, Fontana A, Teixeira WG (2017) Manual de métodos de análise de solo. Embrapa Solos, Rio de Janeiro.

Trautmann RR, Lana MdC, Guimarães VF, Gonçalves Jr AC, Steiner $F$ (2014) Soil water potencial and boron fertilization in growth and uptake of the nutrient for the soybean crop. Rev Bras Ciênc Solo. 38(1):240-251. 
Uluisik I, Karakaya HC, Koc A (2018) The importance of boron in biological systems. J Trace Elem Med Bio. 45: 156-162.

Viçosi KA, Carvalho AS, Silva DC, Almeida FP, Ribeiro D, Flores RA (2020) Foliar Fertilization with Boron on the Growth, Physiology, and Yield of Snap Beans. J Soil Sci Plant Nutr. 20: 917-924.
Vilvert E, Lana M, Zander P, Sieber S (2018) Multi-model approach for assessing the sunflower food value chain in Tanzania. Agric Syst. 159: 103-110.

Zahoor R, Basra SA, Munir H, Nadeem MA, Yousaf S (2011) Role of boron in improving assimilate partitioning and achene yield in sunflower. J Agric Soc Sci. 7(2):49-55. 